\title{
Roger Bastide e a moderna sociologia da arte
}

\author{
Fernando Antonio Pinheiro Filho
}

Por voltada metadedosanos de 1940, Roger Bastideparece sentir a necessidadedecontribuir paraa construção dosfundamentosdeumaSociologiada arte que se expressa em seu livro de 1945, Arte e sociedade, e no presente artigo. $N$ ão por coincidência, no período pós-guerra eleintermeia suas atividades de docência e pesquisa no Brasil, como professor de sociologia na então Faculdade deFilosofia, Ciências e Letras da U SP (ondepermaneceentre 1938 e 1954), com estadas anuais na França, queo põem em contato com a produção local recente. 0 interesse pelo tema da arte remete, assim, a uma dupla inserção em mundos intelectuais diversos, como se a discussão dos problemas da Sociologia da arte tivessem o condão de, pontualmente que seja, sincronizar os tempos do que sefaz na França (enaEuropa) eno Brasil, a partir de uma intervenção que acena para dois dos mundos que convivem em Bastide eque reforça sua posição em ambos. Assim, o texto elabora um balanço do estado dos estudos sociológicos sobre a arte que serve de lastro para a divulgação de uma perspectiva própria e enuncia a consolidação da disciplina como momento do processo de especial ização no interior da sociologia. Se os temas são interdependentes, o primeiro ganha mais sentido no diálogo com a produção européia eo segundo volta-se mais diretamente paraas circunstâncias do desenvolvimento da Sociologia em São Paulo.

Q uanto ao primeiro ponto, Bastide procura evitar a relação de exterioridade entre arte e sociedade postulada (ainda que não explicitamente) pela 
1.Ver a esse respeito $\mathrm{N}$ athalie $\mathrm{H}$ einich, Sociologie de l'art, Paris, Éditions La Découverte, 2004.

2.A esse respeito, consultar o relatório deArbousse-Bastide, "Condiç̄eseorganização do ensino dasociologiana FaculdadedeFilosofia, Ciências e Letras". Sua posição, inspirada pela clivagem temática do AnnéeSociologique, éa que prevalece contra aquela assumida por Claude Lévi-Strauss, que defende uma vociologia que tomasse como objeto os fenômenosdacultura, igualmente inspirada em D urkheim. Fonte: Anuário da Faculdade deFilosofia, Ciênciase Letras da USP, n. 1, 1934-1935. Agradeço a Luiz Carlos Jackson pelosesclarecimentosa esse respeito. maioria de seus antecessores, que consiste em pensar os termos como real idades distintas cujos pontos de contato caberia explicar. Contra essa tendência dominante tanto nos trabal hos inspirados pelo marxismo como na história da arte com preocupações sociologizantes, serve-se de uma concepção relacional da sociedade que contorna o essencialismo elhe permite não pensar a obra a partir do social nem o contrário, mas tomar diretamente a arte como sociedade, segundo a expressão de $\mathrm{N}$ athalie $\mathrm{H}$ einich ${ }^{1}$, encetando a pesquisa das inter-relações entre produtores, mediadores, consumidorese instituições que contribuem para fazer existir o que chamamos de arte. D e outro lado, a insistência na necessidade de especial ização rem ete ao programa então vigente na U SP, que consistia numa clivagem entre as cadeiras de Sociologia I e Sociologia II, obedecendo à divisão entre Sociologia geral e sociologias especiais, conforme a proposta de organização do ensino da disciplina defendida por Paul Arbousse-Bastide². Promover essa divisão do trabalho intelectual éainda uma oportunidade para desenvolver uma linha de pesquisa própria que incluía no debate sociológico sobre a arte questões como a crença, o gosto, os valores, a moda - já indicados no texto. Bastide procurava articular as questões teóricas ligadas ao desenvolvimento da Sociologia francesa com pesquisas empíricas que expressam sua ligação com a realidade brasileira. A consolidação da Sociologia da arte não se desenvolve plenamente, por razões que não cabe discutir aqui. M as, além de seus estudos sobre temas brasileiros como a literatura, a poesia negra, o barroco ou a estética do candomblé, Bastide inspirou, apenas para tomar um exemplo significativo, o importante trabalho de Gilda de M ello e Souza, 0 espírito das roupas, na origem tese orientada por ele e defendida em 1950. N ote-se ainda que o novo campo explorado por ele tem ressonâncias com o domínio da religião, para cuja especialização já contribuíra. A remissão ao conceito de fato social total de $M$ arcel $M$ auss, mobilizado por Bastide, ajuda a compreender seu interesse não só pelos aspectos religiosos da arte - situada por ele no domínio das crenças, vale sublinhar - , mas também pelos aspectos estéticos da religião.

Os três anos que separam o livro de 1945 deste artigo operam uma depuração nas concepções do autor: se a proposta ora desenvolvida já estava presente antes, 0 artigo faz um resumo sel etivo do livro na direção da transição de uma sociologia estética para uma sociologia da estética, a despeito da permanência da primeira expressão no texto. Concretamente, isso significa ultrapassar a mera consideração dos aspectos "anestéticos" da arte, conforme a expressão de C harles Lalo, cujo trabalho serve de apoio a Bastide; 
ou seja, não Ihe basta pregar a desautonomização da arte conjugando a fatura das obras com algum tipo de condicionante externo, mas pensá-la integralmente como coisa social. Aliada aos aspectos já comentados, a passagem contribui para a surpreendente virtude anteci patória e a atualidade das concepções do autor, refratadas em boa parte do que se realiza hoje na área, inclusive no Brasil.

Fernando Antonio Pinheiro Filho é professor do Departamento de Sociologia da U SP. 